\title{
Gender, place and mental health recovery in disasters: addressing issues of equality and difference
}

\section{Akerkar S and Fordham M}

\section{Introduction}

The gendered nature of disaster mortalities has been highlighted through a number of country case studies (including for example, Ikeda, 1995; Oxfam, 2005; Jonkman and Kelman, 2005), however, Neumayer and Plumper (2007) made the first systematic quantitative assessment of gendered mortalities across a range of contexts: in developed as well as developing countries. Their analysis shows that the effect of disasters on women's life expectancy, as compared to men's, is more adverse. They further argue that the extent to which women die at a younger age as compared to men is dependent upon the socioeconomic status of the women in any given country. They assert that 'in countries with better rights for women, the adverse impact of natural disasters on women's life expectancy relative to men vanishes' $(2007$, p. 560). A swift conclusion from such analysis would be that in developed countries where gender equality has been institutionalized through legal frameworks for several years, women and men should expect to experience disaster impacts in similar ways. Indeed, policy makers in several economically developed countries make such a tacit assumption based on the understanding that the gender gap has been eliminated and that there is no need to address gender issues after disasters have occurred (Masson and Langston, 2014).

The UNISDR Regional Synthesis Report 2011-2013 (2013) on implementing the Hyogo Framework for Action for Europe states that $22 \%$ of EU countries engage in gender neutral reporting on disaster recovery and risk reduction strategies. In this regard, United Nations documentation in relation to Europe and disaster response notes that: 'Gender equality has been actively promoted in Europe for decades and European countries often consider gender to be covered in DRR by default, through existing equality laws, education and generally gender-sensitive practices' (United Nations, 2009, p.13). The basis of this assessment is 'the fact that gender equality is enshrined in the law' in EU countries (UNISDR 2013 p.43). For example, The UK government report on the Hyogo Framework for Action National Progress Report (2011-13) states that it does not collect or use gender disaggregated data in its decision making processes or that gender does not inform policy and programme conceptualisation in any meaningful way in their disaster response and risk reduction policy (Government of United Kingdom, 2013). The report argues that this is so because gender is 'not a major issue in the UK as equality law in the UK is designed to ensure that discrimination does not exist for age, gender, disability etc. As such, gender is not being used by the UK to affect decision making, nor to inform policy and programme conceptualisation' (pp. 44-45). In other words, gender equality in law is considered enough 
reason not to engage with gender differentiated strategies, policies and programmes in disaster response and risk reduction.

Our research from two locations in the UK challenges such a tacit and linear assumption made by some EU policymakers including the UK government. Empirical evidence from the UK floods of 2007 in Tewkesbury, Gloucestershire and 2008 in Morpeth, Northumberland show that women and men may experience equal and yet different gendered disaster experience. For example, our quantitative and qualitative empirical evidence shows that although women and men have recovered to mostly equal levels in their mental health after the flooding, predictors for their mental health recoveries are different. Both men and women used different mental health coping and recovery strategies in these contexts. As such, men and women had both equal and different post-disaster experiences.

Further, the evidence shows that, embedded gendered relations and roles in a place (Tewkesbury and Morpeth locations) are strongly co-related with the coping and recovery strategies of men and women. Our findings indicate that traditional forms of masculinity and femininity were predominantly played out in home-neighbourhood places after these floods in the UK which in turn influenced the recovery practices used by men and women. This leads us to conclude that analysis must be contextual and gender and diversity disaggregated in order to be relevant to policy and practices of disaster response in different places. This finding also has implications for European and UK policy responses in the context of disasters.

Limitation of the study: Although we refer to LGBT studies which question the binary construction of gender as male/female in our literature review wherever relevant, our empirical data from Tewkesbury and Morpeth and its analysis is derived from a binary construction of gender, also a result of decision made across the Europe-Asia MICRODIS project team. See for transgender, genderqueer and LGBT studies which critique binary representations of gender and their effects; Gaillard et al (2017), Gaillard et al (2016), Gorman-Murray (2014), Balgos et al (2012), Pincha and Krishna (2008). Further, the small sample size of our study limited our ability to examine the intersections of gender with other social aspects such as age, disability and ethnicity.

The paper is structured as follows:

It starts with a critical review of literature on relations between gender, place and disasters. It reviews two bodies of literature: one highlighting the relations between gender, place and disaster, and another reviewing existing literature, if any, on micro experiences of gender, place and mental health in disaster. Our review shows that much of the literature on microexperience of place and mental health in disaster is gender neutral. Our study which uses gender as an analytical category, contributes to addressing this gap, and makes a new knowledge contribution on this issue. Building upon its empirical evidence, it goes on to develop a conceptual framing that links place, gender and mental health in the context of 
disasters. This is followed by a section which presents and discusses our empirical findings with regard to floods in Tewkesbury and Morpeth, in the UK.

In the last section, in the light of our conceptual framework and empirical findings, which highlight the importance of gender relations and place in understanding the gendered mental health patterns in disaster, we critically discuss the current disaster response and policy frameworks related to risk reduction within the UK and other countries within the EU. Questioning their gender-neutral policy framework, we argue that the idea of gender neutrality needs to be deconstructed and contend that gender differences are all-pervasive. We thus call for general gender and diversity mainstreaming in disaster policy and practice, and specifically for developed socio-economic country contexts, including the UK.

\section{Critical literature review and development of conceptual framework}

The link between place and disasters has often been made through the idea of place vulnerability or 'hazards of place' in disaster literature (Cutter, 1993, 1996), suggesting that certain localities, and people living in them, are more vulnerable to disasters. One attributed reason is the proximity of such places to hazards and probable disaster events. Thus, for example, coastal places are more susceptible to tsunamis and cyclones than hinterlands, just as places on fault lines or tectonic plate boundaries are more vulnerable to earthquakes. The other attributed reason is the level of socio-economic development of place as it affects the capacities of the affected countries and people to cope with disasters (O Keefe et al 1976; Hewitt, 1983; Blaikie et al 1994; Cutter, 1996; Wisner et al 2004). As early as 1976, O'Keefe et al had shown that many of the disasters were in the developing countries: thus suggesting that they were a result of social vulnerability rather than effects of natural agents. Hewitt had then further noted that disasters are dependent upon social orders and everyday relations within a habitat (Hewitt, 1983). Building upon this, Wisner et al have argued that 'people's exposure to [disaster] risk differs according to their class (which affects their income, how they live and where), whether they are male or female, what their ethnicity is, what age group they belong to, whether they are disabled or not, their immigration status, and so forth' (Wisner et al 2004, p. 6; Blaikie, et al 1994). Vulnerability is thus better understood as embedded in social processes and relations that lead to differential impacts for hazard affected persons (Kelman et al 2016; Bankoff et al 2004; Oliver-Smith and Hoffman 1999; Lewis, 1999). Empirical evidence of gendered impacts of disasters has been further captured through mainly qualitative studies of disasters, supported at times with survey data (Reyes D and Lu J 2016; Masson et al, 2015, Fakruddin and Rahman, 2015; Alam and Rahman 2014; Eirksen, 2014;Bradshaw, 2014, 2004, 2002, 2001; Bradshaw and Fordham 2013; Brown, 2012; 2004; Irshad and Mumtaz, 2012; Enarson, 2012a, b; Enarson and Chakrabarti, 2009; Enarson and Myreles, 2004; Enarson and Fordham, 2001a, 2001b; Enarson and Morrow, 1997; Fordham, 2009; Fordham 1998; Fordham and Ketteridge, 1998; Houghton, 2009; Jenkins and Phillips, 2008, Cupples, 2007; Akerkar, 2007; Ariyabandhu, 2006, Oxfam, 2005; Fothergill 1999; Hoffman, 1998, 1999; 
Ikeda, 1995). The themes covered by these studies, which were carried out in different country contexts, both developed and developing, include: gendered nature of disaster relief and recovery work, gender and resilience, gendered roles and labour after disasters, violence against women after disasters, gendered socio-economic impacts of disasters, gendered impacts of disability after disasters, and gendered mortalities. The study by Neumayer and Plumper (2007) stands out, as it undertakes a systematic quantitative analysis of gendered disaster impacts: (in particular, gendered mortalities) and their relation to disasters in the context of differential socio-economic development.

While the above literature provides a global macro perspective on gender, place and disasters, a different body of literature has provided a micro perspective on the specifics of place. Massey $(1994,2005)$ contends that space is not just about how things are arranged in a physical location or a place: rather, space and place are related through how social relations, including gender, are socially constructed in those places. Space is constructed from social relations; it is social relations 'stretched out' in a place (Massey, 1994, p.2). Thus homes and Neighbourhoods can be conceptualised as places at different spatial scales constructed and shaped by social relations inscribed in these spaces (Coates and Fordham, 2000). Massey et al also argue that places as social environments, are 'activity spaces' (Massey and Jess, 1995, p.59), where households and communities interact, and develop a sense of belonging to and identity with those spaces. As such, homes are also affective spaces and places shaped by emotional feelings and a sense of belongingness and attachment (Foresight Future Identities 2013). Homes are embodied spaces where 'physical location and psychological or emotional feeling are tied rather than separate or distinct' (Blunt and Dowling, 2006 p.22). That is, memories, emotions and the physical structure are closely aligned with the idea of home (Blunt and Dowling, 2006). Black (2002) also argues that "the concept of "home" is not straightforward. It is intimately linked to concepts of identity and memory as much as territory and place. Home can be made, re-made, imagined, remembered or desired; it can refer as much to beliefs, customs or traditions as physical places or buildings. Most important, as a concept it is something that is subject to constant reinterpretation and flux, just as identities are renegotiated' (Black, 2002 p.126). In other words, homes are important material and symbolic sites from where women and men orchestrate their social lives and relations, and reinvent their social identities in fluid ways as our findings also indicate (Dyck 2005). Similarly neighbourhoods can be conceptualised as a 'meeting-place, the location of the intersections of particular bundles of activity spaces', carried out through the participation from men and women of a locality (Massey and Jess, 1995, p. 59). Homes and neighbourhoods as places of attachment are found to be gendered (Guillani and Fieldman, 1993, Moore, 2000). Further, social factors such as both personal and social relationships (family, friends, and neighbours) shape the meanings of homes and neighbourhoods (Coates and Fordham, 2000). In the context of disasters, this suggests that changes in personal and social relations following disasters can lead to changes in the meanings attached to disaster affected localities (homes and neighbourhoods) and in turn 
affect mental health of affected men and women. More generally, meanings of homes as both 'material and imaginative' structures, are altered by forced displacement through disasters leading to psychological distress (Brun and Lund, 2008).

Norris et al (2002a, 2002b) have reviewed a sample of more than 60,000 individuals who have experienced 102 different disaster events, and noted links between micro-experience of place with mental health after disasters. They note people's concerns about their living places and spaces, and suggest that 'chronic problems of living', 'troubled interpersonal relations', 'new family strains', 'perceived social support' and 'social embeddedness' as key factors which affect people's mental health after disasters (Norris et al 2002a, p 216-217). Chae et al 2005 argue that '[n]atural disasters deprive people of their means of living, sense of place, and social support networks. As a result, significant stress can cause serious deterioration of physical and mental well-being' (Chae et al 2005 p.635). Bourque et al (2006) note that disruption of social networks can be a significant stressor after disasters. Gray (2008) contends that in the context of the 2007 Hull floods, 70\% of those who moved home as a result of the flooding reported mental and/or physical health problems. Sawa et al (2013) show relations between psychological distress and displacement after tsunami in Japan in 2011. Similarly Toyabe et al 2006 show high levels of psychological distress among elderly who were displaced into living in temporary shelters after Niigata-Chuetsu earthquake in 2004 in Japan. Reflecting on home and Hurricane Katrina and the Pakistan/Kashmir earthquake 2005, Blunt and Dowling (2006) note that these disaster events 'are also about home - disruptions to belongings and attachment - as well as the loss of shelter...' (p.259). Questioning the Cartesian divide between mind and body, AdamsHutcheson (2016) argues that the psychological trauma experienced by persons after a loss of home as a result of the Christchurch earthquake of 2010 needs to be understood as 'embodied' phenomena.

In the context of the UK, Tapstell and Tunstall (2008) in their longitudinal study of two communities in Oxfordshire, flooded in 1998, show that the floods had a long lasting psychological effect on flooded persons, with disruption of daily life, leading to disruption in their sense of meanings associated with their sense of living space and place. Carroll et al 2009 also find after the floods in Carlisle in 2005, that place-based identities, such as when meanings attached to home are disrupted due to displacement after disasters, can be a source of trauma. They conclude: 'Disasters do not merely make people become unsettled, they attack and break the bonds of continuity, familiarity and attachment to the home' (Carroll et al 2009, p. 545). As Mason et al 2010 argue, exposure to flooding in itself 'does not fully explain the onset of PTSD as many individuals do not develop such symptoms. Indeed, events are not inherently traumatic', and place based attachments contribute to such experience (Mason et al 2010 p.61). To summarise, as the above literature shows, social variables such as place-based attachments (homes, communities and neighbourhood, social networks and dynamics) contribute to whether and how trauma is experienced after disasters. Although the above literature links micro experiences of place with mental health 
after disasters, it is mainly gender neutral, that is, dimensions of how gender, place, mental health after disasters are linked are generally not analysed in these studies Tapsell and Tunstall (2008) study does have some narratives by women about their experience of stress due to disruption, dealing with recovery with no help, however gender is not central to their analysis. Others such as Suzuki et al 2015, Yoshii et al 2014, Dell'Osso et al 2013; Willinger 2008; Varela et al 2008; Aksaray et al 2006 Garrison et al 1993, Glesar, Green and Winget, 1981 have noted gendered mental health effects after disasters, however their relations with place as a social construct is not adequately analysed. After hurricane Katrina in 2005, Willenger (2008), Overstreet and Burch (2008) notes that women were 2.7 times more vulnerable to posttraumatic stress than men, and 1.5 to 2 times more vulnerable to heightened anxiety than men, owing to parenting and caring stress. Women were more likely to be psychologically distressed among those evacuated after the Fukushima nuclear radiation after the tsunami in 2009 in Japan (Suzuki et al 2015). Pregnant women who were exposed to Fukushima nuclear radiation showed high levels of maternal anxieties about its effect on embryos, children, and food safety among others (Yoshii et al 2014). Varela et al (2008) also note that women's stress levels were marginally higher than those of men after the earthquake in Greece in 1999 (Varela et al. 2008). Other studies which have shown higher propensity of women to be traumatised than men, are Henderson and Elsass 2015 in relation to Sri Lankan tsunami of 2004, Dell'Osso et al 2013 after L'aquila earthquake of 2009, and Aksaray et al 2006 after the Turkey earthquake in 1999.

A systematic literature review on health impacts of disasters by Nomura et al (2016) shows that studies have looked at variables such as gender or place and their impacts on mental health separately. Our paper specifically looks at their interconnections, using gender as an analytical category to understand linkages between micro experiences of place, and mental health impacts after disasters. Here, we also draw from studies analysing how disasters can affect the ontological security of persons after disasters. After Giddens, Hawkins and Maurer (2011) identify the concept of ontological security as 'psychological protection from anxiety of uncertainty and risk provided by ..... home place and value of community'. Displacement experiences after Hurricane Katrina led to mental trauma as they destabilised the ontological security of the affected persons (Hawkins and Maurer, 2011). Gorman-Murray et al (2014) have highlighted how displacement after the Christchurch earthquake in 2010 lead to loss of wellbeing and ontological security of LGBT persons, given their specific vulnerability due to social stigma attached to these identities. We find that the concept of ontological security is useful to further analyse the mental health outcomes, the mental health recovery strategies used by men and women and their relationships with homeneighbourhood places. This is further discussed in our empirical findings and discussion sections.

Our empirical evidence leads us to depict the conceptual framing of the relation between gender, place and mental health as in the following figure 1 
Figure 1: Conceptual framework: gender, place and mental health after disaster

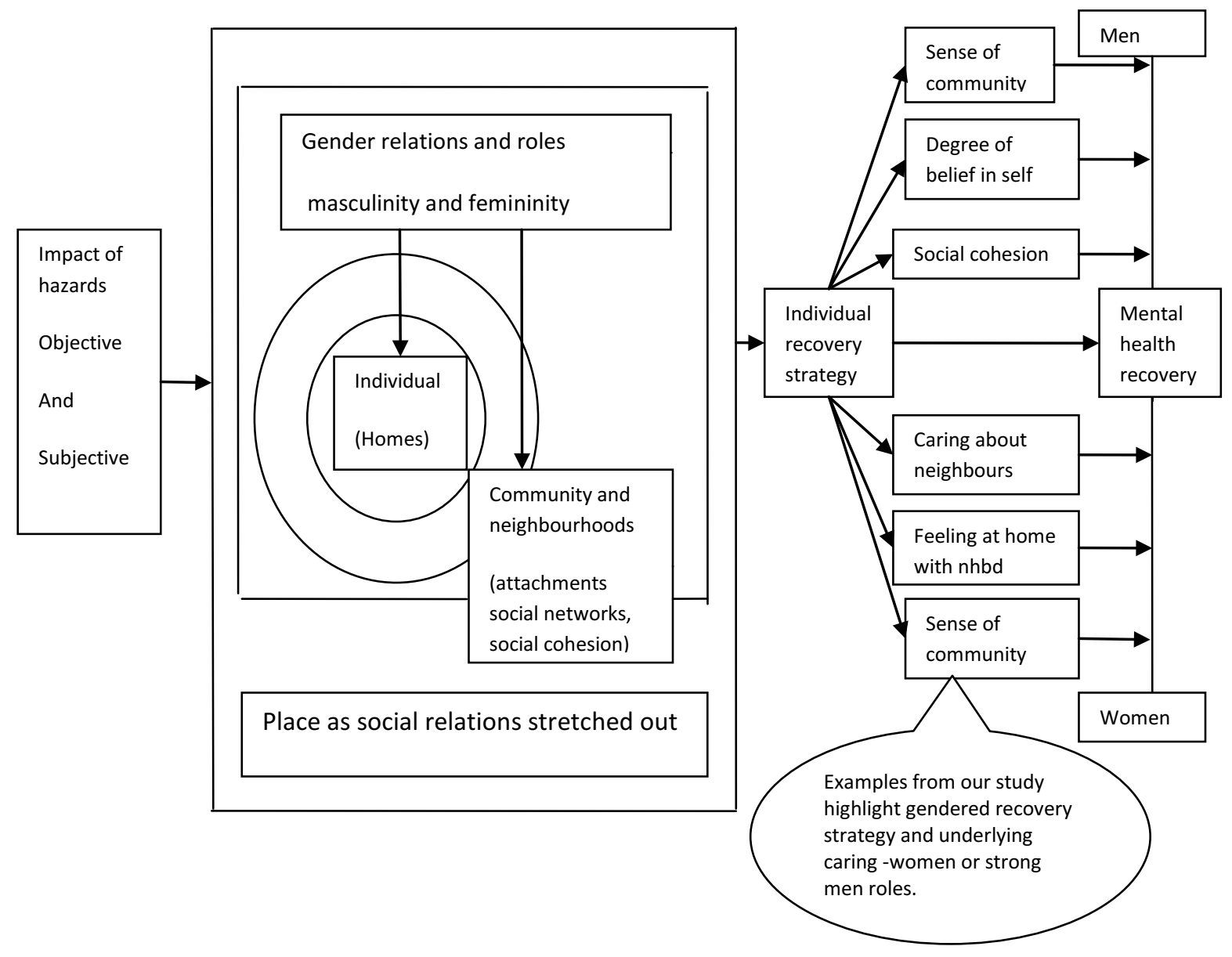

Figure 1 shows the linkages between disaster impacts and gendered patterns of mental health recovery. At the far left of the figure, are shown both objective and subjective impacts of the hazards. The objective dimension, for example, refers to the actual losses experienced such as loss of a home, or damages to the home, while the subjective dimension refers to the experience of that loss, the meanings given to that loss. The subjective experiences of that loss are mediated through experiences of place and space by the individuals. In the above Figure 1, we conceptualise place as embodying social relations 'stretched out' (Massey, 1994). This stretching out is shown through two concentric circles in the above figure, each signifying individuals living in their homes, and respectively among neighbourhoods and communities. In particular, we focus on gender relations, gendered roles and their constructions in both these spaces: homes and neighbourhoods/communities. We conceptualise neighbourhoods as spaces and places where gender-based attachments, social networks, social cohesions and community 
dynamics are played out. Similarly, homes are places where gendered roles are played out, including constructions of identities: masculinity and femininity. This conceptual embedding of place and gender plays a crucial mediating role in the way in which disasters are experienced by individuals living in these spaces. When hazards strike, these gendered places advance individual trauma coping and recovery strategies that are highly gendered. In our study from flood affected areas of the UK - Tewkesbury and Morpeth, as given below - we found that although the mental health outcomes for men and women were mostly equal, that is both recovered to a mostly equal degree; the subjective experience of the same was different; captured through differential trauma coping and recovery strategies used by men and women.

In the above conceptual framework, we highlight examples of gendered mental health recovery strategies used by affected men and women from Tewkesbury and Morpeth. For affected women, the recovery strategies were mediated through social place variables such as sense of community, feeling at home within the neighbourhood, and caring about neighbours; while for men, it was through sense of community, social cohesion and degree of belief in self. The significance of these findings is discussed in more detail in the empirical discussion given below. However, in summary, we show that the use of different strategies is guided by gendered socialisation and identity formations: namely, notions of masculinity and femininity, associated, respectively, with strong protector or provider roles played by men, and 'caring' roles by women. It confirms our conceptual perspective, that men and women have used different coping and recovery strategies, in turn highlighting the complex relations between gendered role constructions, identities, place and wellbeing after disasters.

In the next section, we discuss the results of our study from Tewkesbury and Morpeth, which were affected by major floods in 2007 and 2008 respectively.

\section{The study context of the UK: Tewkesbury, floods in 2007 and Morpeth floods in 2008}

The district of Tewkesbury received $80-90 \mathrm{~mm}$ of rain on the $20^{\text {th }}$ July 2007 , which amounts to almost two months' rainfall in just one day and caused severe surface water flooding of the town from the rivers Avon and Severn. An estimated 810 properties were affected by flooding in Tewkesbury, with the centre of town being completely cut off (Environment Agency 2008). Fifteen hundred buildings were flooded in Tewkesbury by both flash and fluvial flooding (Stuart-Menteth 2007).

Morpeth experienced a severe flood on 6 and 7 September 2008, when the Wansbeck river rose well above its banks and overtopped and damaged the town's flood defences. A peak water level of 3.99 metres was recorded in the river channel, the biggest flow ever recorded in the Wansbeck. Overall the flood caused direct damage to 1,012 properties, including 913 residential properties of which 615 were 'severely affected'. Many people were displaced 
and the economic damages were probably the greatest ever experienced in Morpeth (JBA, 2008).

A study of social impacts of floods was undertaken in Tewkesbury and Morpeth in 2009 as a part of the EU FP6 project MICRODIS ${ }^{1}$. Quantitative as well as qualitative methods were used to collect the data from flood affected people. A survey questionnaire was administered to randomly sampled flood affected persons in Tewkesbury in January 2009, about one and half years after the floods in July 2007, and in Morpeth in August 2009, about one year after the floods in September 2008. In all, 136 flooded households were interviewed in Tewkesbury, of which 60 were men and 76 women respondents. In Morpeth, a randomly selected sample of 236 flooded households was interviewed of which 90 of the respondents were men and 146 of them women. The qualitative data in Tewkesbury and Morpeth was collected using two tools: Firstly, open-ended questions were asked after the survey questionnaire was completed, and qualitative comments given by the respondents were noted. Secondly, in Morpeth, additional separate qualitative interviews were conducted with 20 flood affected persons.

The survey questionnaire assessed various social constructs to understand the relation between mental health and its predictors for groups of men and women. It has assessed mental health of persons using MHI5 questions and SF12 questions. Both these constructs ( $\mathrm{MHI} 5$ and SF12) are widely used in understanding mental health issues and this study has used the standardised questions to assess the same (Ware, Gandek, and Kosinski, 1998; Pevalin, 2000; Ware, 2002; Kelly, 2008; Henderson and Elsass, 2015). SF12 constructs included 12 questions, namely on Bodily pain (1), Energy/Vitality (1), General health (1), Mental health (2), Physical functioning (2), Role limitation-emotional (2), Role limitationphysical (2), Social functioning (1). The MHI5 included 5 questions, to measure psychological wellbeing and symptoms of psychological distress of the person at the time of interview. The answers to these MHI5 and SF12 questions were measured on a Likert scale (1-5), and converted into a score on a scale of 100 .

Similarly, given the literature review (Norris, 2002a, 2002b; Chae et al 2005; Bourque et al 2006; Gray, 2008; Tapsell and Tunstall, 2008; Carroll et al 2009; Mason et al 2010, Henderson and Elsass, 2015) which had found links between place and mental health, social constructs linked with place-based attachments and cohesion were assessed in the questionnaire at two levels: neighbourhoods and home. Since homes and neighbourhoods are considered as place based communities embedded in locality based social relations (Massey 1995; Blokland, 2001, Forrest and Kearns 2001), sense of community was assessed through a series of questions on neighbourhood relations, attachments and dynamics within

\footnotetext{
${ }^{1}$ See http://www.microdis-eu.be/ Although this research was funded by the European FP6 6th Framework Programme under The MICRODIS Project - Integrated Health, Social and Economic Impacts of Extreme Events: Evidence, Methods and Tools (Contract No GOCE-CT-2007-036877) the responsibility for the findings in the paper lies solely with the authors and not with any other persons or the EU.
} 
neighbourhoods, while home based attachments through questions on personal relations in homes and help/support from family and friends.

Additionally, a literature review (Garrison et al. 1993; Glesar et al 1981) had suggested that social constructs such as people's beliefs and subjective interpretation of events can play a role in trauma coping and recovery strategies. Hence personal beliefs, such as perceived abilities of self to recover, were also assessed on an ordinal scale. Further, perceived trauma and severity of the same floods were also measured to identify the subjective interpretation of the event. These social constructs were further analysed for their effects on mental health using regression and correlation analysis for flood affected men and women in Tewkesbury and Morpeth.

In terms of limitations of our study, as stated in our introduction, we note that apart from gender, other demographic variables such as age can have a bearing on mental health after disasters. Although our study did not find any statistical relation between gender, age and mental health, we note that our sample size when disaggregated by sex and further with age may have been too small to find any such relation.

\section{Research Questions}

The main research questions for the study were: How have floods affected the mental health of men and women? How have place-based social constructs and beliefs affected mental health outcomes of flood affected men and women?

\section{Thematic findings of the study}

\subsection{Men and women recovered well and mostly equally in mental health after the floods}

The data analysis examined the role of gender norms, roles and expectations in the achieved mental health using MHI5 and SF12 questions. Using gender as a variable, Table 1 shows that there are marginal (and not statistically significant) differences in the mean mental health MHI5 and SF12 scores for men and women. The mean MHI5 score for women was 77.8 and that for men was 81.33 in Tewkesbury, while that in Morpeth was 75.64 for men and 72.09 for women. Similarly, the mean SF12 score for women in Tewkesbury was 64.09 and that of Men 70.69; while that in Morpeth was 71.32 for men, and 70.78 for women. Since both men and women as groups have a mental health score of more than 50 a threshold below which affected persons are reported to have post-traumatic stress disorder (PTSD) which affects their daily lives - these findings suggest that, although there were marginal differences between the scores, with men doing slightly better than women; both men and women have recovered well enough to be stated in an overall condition of 
average mental health after one and half years of flooding in Tewkesbury, and one year of flooding in Morpeth.

Table 1: Mental health scores of men and women in Tewkesbury and Morpeth

\begin{tabular}{l|l|l|l|l|}
\cline { 2 - 5 } Flooded Group (Tewkesbury) & Gender & $\begin{array}{l}\text { Number of } \\
\text { respondents } \\
\text { (N) }\end{array}$ & $\begin{array}{l}\text { Tewkesbury } \\
\text { (\%) }\end{array}$ & $\begin{array}{l}\text { Morpeth } \\
\text { (\%) }\end{array}$ \\
\hline Mean MH15 score & Male & 60 & 81.33 & 75.64 \\
\hline & Female & 76 & 77.8 & 72.09 \\
\hline Mean SF12 score & & & & \\
\hline & Male & 90 & 70.69 & 71.32 \\
\hline & Female & 146 & 64.07 & 70.78 \\
\hline & & & & \\
\hline
\end{tabular}

However, as given below, the findings also showed that while both men and women have recovered in their mental health more or less equally from the PTSD perspective, in both Tewkesbury and Morpeth, the floods had disrupted their sense of home leading to stressful conditions after the floods, with women in general experiencing this disruption and loss subjectively more than men.

2.2) Gender differences were found in subjective interpretations of the flood event, and perceived trauma, which in turn are linked with changes in the perceptions of men and women about their homes following floods. Floods changed the perceptions of men and women about their home as a safe and secure place.

Floods were experienced as very severe and more traumatic by the majority of affected populations, with women experiencing it more intensively than men as shown in Table 2 and 3, although no statistically significant relation found between severity or experience of trauma and mental health. Seventy-five percent of women found the floods very severe as compared to $\mathbf{5 7 . 6}$ percent of men in Tewkesbury. In Morpeth, 87.4 percent of women found the floods very severe as compared to 80 percent of men.

Table 2: Experience of floods as 'very severe'

\begin{tabular}{|l|l|l|}
\hline $\begin{array}{l}\text { Percentage who experienced floods } \\
\text { as 'very severe' }\end{array}$ & Tewkesbury (\%) & Morpeth (\%) \\
\hline Males & 57.6 & 80 \\
\hline Females & 75 & 87.4 \\
\hline
\end{tabular}


A higher percentage of women than men felt traumatised by the floods to a 'high' extent in both Tewkesbury and Morpeth as shown in Table 3. 69.8 percent of women as compared to 53.4 percent of men found the experience of floods highly traumatic in Tewkesbury. Similarly, 74.7 percent of women as compared to 55.6 percent of men were highly traumatised in Morpeth by the floods.

Table 3: Trauma due to floods

\begin{tabular}{|l|l|l|}
\hline $\begin{array}{l}\text { Percentage who felt traumatised by } \\
\text { floods to a 'high' extent }\end{array}$ & Tewkesbury (\%) & Morpeth (\%) \\
\hline Males & 53.4 & 55.6 \\
\hline Females & 69.8 & 74.7 \\
\hline
\end{tabular}

The above findings from Tewkesbury and Morpeth corroborate those of other studies identified in literature review which suggest that women bear higher mental stress than men in disasters. Further, this finding also confirms those of other studies namely, Garrison, et al 1993 after Hurricane Hugo in 1990, and Glesar et al 1981 after dam collapse in Buffalo creek in 1972, which argue that the susceptibility of men and women to higher mental stress is also attributed to their subjective interpretation of events.

In our qualitative questioning, women in particular linked the perceived trauma with their feeling of insecurity and lack of safety in their homes. P, a woman from Morpeth who had three young children, felt that her home was no more a safe and secure place, and she worried about the flooding happening again:

'The horrible thing is I don't feel safe over here anymore ... you know what I mean ... In your house, you should be able to come in and feel safe, but I don't feel like that anymore ... there is a little bit at the back of my mind, where you think that if it has happened once, it can happen again, no matter what others say ...'

Such loss of sense of security and safety in relation to one's home has also been reported by Fordham (1998) in relation to Scottish floods. Hawkins and Maurer (2011) also highlight the effect of disruptions of home on mental trauma after Hurricane Katrina.

\subsection{Loss and disruption experienced as a result of displacement following floods, led to stressful interpersonal relations for some men and women.}

The mental trauma was also attributed to the experience of displacement and disruption of homes after the floods, with qualitative interviews suggesting that women experienced the 
temporary loss of home and neighbourhood attachments more intensively than men. A man who is a doctor by profession from Morpeth explained this perceived trauma difference between himself and his wife, when they had to live in another place for more than four months:

'I was more anxious about my wife's health ... She became quite depressed ... We were a mile away from the town, and she simply could not manage on her own unless I brought her by car. So she was quite depressed by that, and she was not able to do an awful lot ... It was a winter time, and none of the [new] neighbours were in the garden, therefore we didn't get to know our neighbours very easily ... And I think the whole thing for her was also much emotional, eh from emotional point of view it was very stressful for her ... and she is still suffering from it. She still has episodes of weepiness and that is partly why she does not want to speak to you [the interviewer] ... But there it is. It was quite stressful for her. I had the advantage of plenty to do dealing with the contractors ... and so the problems kept me busy ... My wife sought help from general practitioner for her depression which was not very helpful as it did not deal with the root cause. She is much better since we have been back ...'

With displacement, home as a space for secure interpersonal bonding relations also underwent change. In both Tewkesbury and Morpeth, some women and men experienced a change in their personal relationships following the floods. For example, 11.9 percent of men as compared to 29.1 percent of women in Tewkesbury, and 11.1 percent of men and 10.9 percent of women experienced changes in their personal relations to a high extent: as shown in Table 4:

Table 4: Change in personal relations

\begin{tabular}{|l|l|l|}
\hline $\begin{array}{l}\text { Experienced change in personal } \\
\text { relations to a 'high' extent }\end{array}$ & Tewkesbury (\%) & Morpeth (\%) \\
\hline Males & 11.9 & 11.1 \\
\hline Females & 29.1 & 10.9 \\
\hline
\end{tabular}

When probed further in our qualitative interviews ${ }^{2}$ on the nature of this change in both Tewkesbury and Morpeth, data shows that while a few families experienced positive change (families bonding more after disasters), also known as post-traumatic growth (Tedeschi and Calhoun 2004; Ikizer et al 2015), others found the change to be negative:

\footnotetext{
${ }^{2}$ These are in some cases, interviewer notes appended to the questionnaires and not verbatim transcripts.
} 
Interviewer notes recorded a range of response ${ }^{3}$. We highlight few examples of the same from these notes:

A middle aged male from Tewkesbury: 'affected to a high extent, more stressful, there were more family arguments, obviously as we were all staying in a caravan'.

A middle aged woman from Tewkesbury: 'had arguments in home about lack of involvement of husband'.

In Morpeth too, staying in Caravan was identified as one reason for stress: 'Argued a lot through stress - put a lot of pressure on us both'.

Another Man from Morpeth: 'Moved in with partner and we had to do the building work together, lots of arguments and pressure on both sides'.

The stress led to depressions which in turn affected personal relations in negative ways. A middle-aged man from Tewkesbury said: 'I've been depressed and became more quick tempered'. A woman from Morpeth: 'I thought I might leave him ... he was moody ... he became very nervy and depressed'.

For some relationships this stress led to separation. A middle aged man from Tewkesbury recalled: 'Children rallied around ... But it was final straw in relationship with wife. Increased tension led to divorce'. A young flood-affected man from Morpeth who had moved in with his girlfriend said that they had problems which caused them to split up.

2.4 Positive interactions within community spaces and neighbourhoods were important for both men and women to cope with the trauma of the floods. Men and women were well embedded in their neighbourhood community; however they experienced this place differently in social terms. Equally, displacements from their familiar neighbourhood community spaces, even if temporary, were traumatic and stressful.

The sense of community as a construct was measured through a number of questions using a scale 1-5 (1 as very low, and 5 very high) on men's and women's perceptions of their neighbourhoods: as well as the level of their interaction with their neighbourhoods. The measure shows that both in Tewkesbury and Morpeth, the flooded community had a strong sense of community, which was equally strong amongst men and women: as shown in Table 5. On the construct: sense of community, men had an average score of 4.3 and women 4.5 in Tewkesbury. In Morpeth, men scored 3.75 and women 3.71.

Table 5: Sense of community

\begin{tabular}{l|l|l|l|}
\hline & & $\begin{array}{l}\text { Tewkesbury } \\
\text { (mean) }\end{array}$ & $\begin{array}{l}\text { Morpeth } \\
\text { (mean) }\end{array}$ \\
\hline Sense of & Male & 4.3 & 3.75 \\
\cline { 2 - 4 } & &
\end{tabular}

${ }^{3}$ Interviewer notes are notes taken by the interviewers during the interview and are not verbatim transcripts. 


\begin{tabular}{l|l|l|l|}
\hline community & & & \\
\hline (Scale 1-5) & Female & 4.5 & 3.71 \\
\cline { 2 - 4 }
\end{tabular}

These findings suggest that women and men were well and positively embedded in their community places in both Tewkesbury and Morpeth.

Consider this conversation between a husband $(I)$ and wife $(A)$ who had stayed in a rented bungalow in Morpeth for four months after the floods and were very glad to be back in their own house:

A: it is a close community.

I: we missed them... Although our next door neighbours were just a street away [in displaced place] ... It was winter ... and we hardly saw them ...

A: it was quite lonelier then ...

I: our social life did not change because we still saw friends, but we missed the neighbourly stuff ... But now we are back and everybody drops in to the garden and talk ... We missed this neighbourly stuff then ... We were the first persons back, and it was quite lonely ... quite spooky ... that lasted about three weeks ... and people slowly started to come back then ... it was not very pleasant to be very honest ...

I: we generally felt eh ...

A: very depressed

I: yes depressed.

A: [addresses I] you are not a depressed person are you? But he was quite depressed. But I am depressed kind of a person so it was sort of normal but only worse ... but he was depressed .... in the first week [after the floods] the houses sort of smelled of sewage and ... that was difficult ...

I: we were drinking much more

A: we would have a bottle of wine between us every day ... as that would relax us a bit....

Like the above couple, others who were temporarily displaced were nostalgic about their loss of a familiar neighbourhood and recalled the trauma they underwent during their displacement. Morrice (2013, p.3) highlights a similar 'emotional nostalgia' by those displaced after Hurricane Katrina who imagined their homecoming as a return to the place of familiarity.

Return to their homes and interactions with their neighbours and the community was a part of their healing process. When displaced, living away from their neighbours was hard as one of our respondents recalled: 
'I missed everyone here [the neighbours] and that was the hardest part. The rest of community which had not gone through [floods] were good but they really did not understand.'

Another woman from Morpeth recalled:

'You know ... We all were much traumatized. We did not have family in the area. Our friends were great ... Really at that time; I wanted to be near people who had experienced the same thing like me. My friends were fantastic, but I would come here to speak to my neighbours because at that time they were the only ones who knew what we went through. And so we all badgered along ... you know ... as we had been through the same thing ... So that's how we got the emotional support. We helped each-other practically also. ... For example, my neighbours could not move stuff we helped ... I am not alone and that helped ... We gave each other a lot of support ... We are more connected now. Even before we got on very well, but ... now we are ... like - if we need things now we are more likely to go to each other. Earlier I would be hesitant if I needed anything ... We got to know each other more now'.

Another woman respondent from Morpeth emphasised the increase in their community spirit after the floods:

'That is one of the good things that have come out of the floods. Everybody pulled together. The community spirit was great. People helped each other. Everyone was checking on everyone whether they were ok. Whether they needed anything. We went to temporary accommodation but we swapped the telephone numbers. ... '

Both men and women found community spaces and their neighbourhoods a source of strength, and evaluated them in positive terms. However, a deeper analysis, suggests that there were subtle differences in the ways in which women and men experienced community interaction after the floods.

Women in both Tewkesbury and Morpeth had more and different contacts after floods than men. As shown in Table 6, 61.9 percent of women as compared to 49 percent of men in Tewkesbury stated that they had more and different contacts in their neighbourhoods after the floods. Similarly, in Morpeth about one fifth (19.1 percent) of women said that they had contact with more and different people in their neighbourhoods as compared to 12.2 percent of men after the floods. As one woman stated 'I have had more contact with neighbours. It has as a community brought us much closer together, especially the women'. Another woman emphasised that the closeness continues although flooding is over: 'The 
feeling of connectedness is still present, as the women in the neighbourhood still go out to dinner with each other once a month'.

Table 6: Contacts in neighbourhoods after floods

\begin{tabular}{|l|l|l|}
\hline $\begin{array}{l}\text { More and } \\
\text { different } \\
\text { contacts in } \\
\text { neighbourhood } \\
\text { after floods }\end{array}$ & Tewkesbury (\%) & Morpeth (\%) \\
\hline Male & 49 & 12.2 \\
\hline Female & 61.9 & 19.1 \\
\hline
\end{tabular}

Women and men also had different neighbourhood social networks suggesting that they experienced their neighbourhoods differently. In Morpeth, people were given maps to draw the boundaries of their neighbourhoods. Husbands and wives, although staying at the same address, drew very different boundaries for their neighbourhoods, an example of which is given in Figures 2 and 3 below.

Figure 2: Community Neighbourhood boundary drawn by a man (husband) in Morpeth

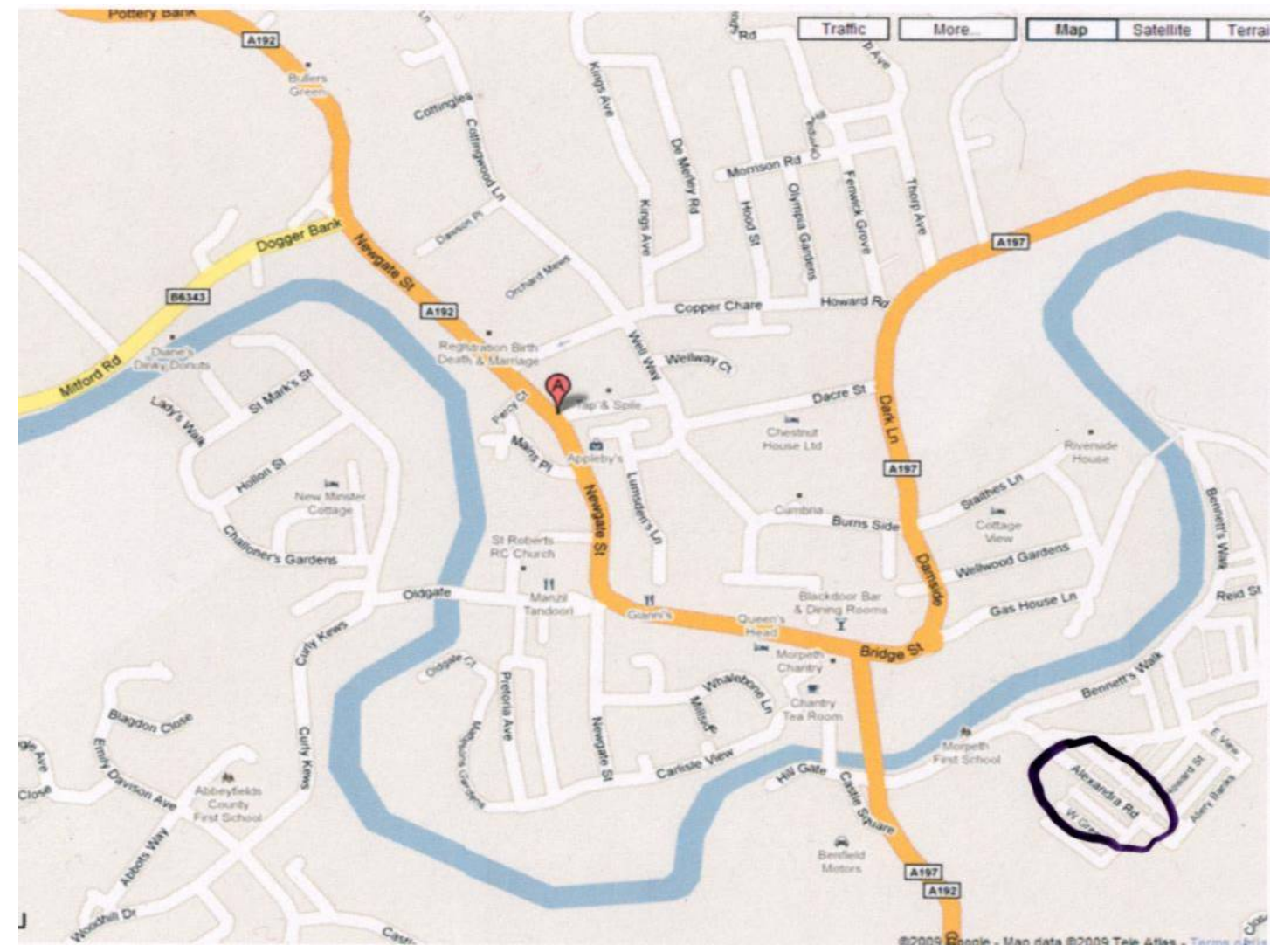


Figure 3: Community Neighbourhood boundary drawn by a woman (wife) in Morpeth

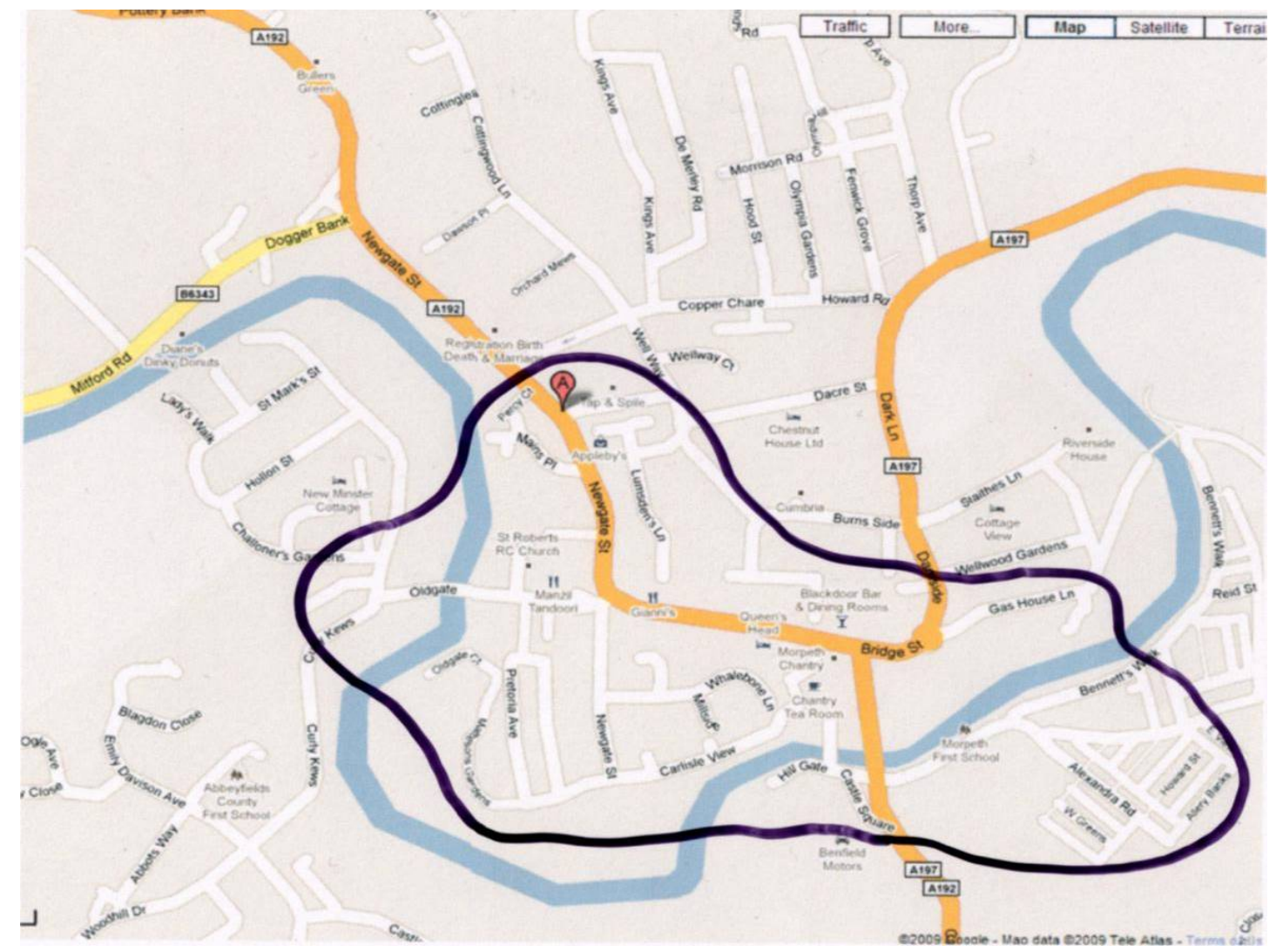

Figures 2 and 3 shows that men and women living in the same house had very different experience of their neighbourhoods, and hence very different neighbourhood contacts, relational networks and social experiences.

2.5 Mental health although mostly equal in men and women (as discussed in Table 1) was further found to be predicated upon different coping and recovery strategies by men and women. As we show below, the mental health coping and recovery strategies used were highly gendered, and were informed by traditional notions of masculinity and femininity held by the affected men and women. This shows a complex relation between gendered identities, roles, home-neighbourhood places and well-being.

In Tewkesbury, as shown in Table 7 below, regression analysis has shown that the main predictor for mental health recovery (MHI5 an SF12) for women was their emotional relations with their community, expressed through a caring neighbourhood relation, feeling at home in the neighbourhood; while for men it was the degree of perceived control, their belief in their own ability to deal with the post flood situation, and doing things to improve the situation.

Table 7: Predictors for mental health in Tewkesbury

Dependent $\quad$ Predictors identified using regression




\begin{tabular}{|c|c|c|c|}
\hline \multirow[t]{2}{*}{ variable } & \multicolumn{3}{|c|}{ analysis for Tewkesbury } \\
\hline & Males & Females & $\begin{array}{l}P \text { value (level } \\
\text { of significance) }\end{array}$ \\
\hline SF12 & $\begin{array}{l}\text { Degree of } \\
\text { belief in } \\
\text { ability to } \\
\text { deal with } \\
\text { the } \\
\text { situation } \\
\text { Degree of } \\
\text { doing things } \\
\text { to improve } \\
\text { the } \\
\text { situation }\end{array}$ & $\begin{array}{l}\text { Caring } \\
\text { about } \\
\text { neighbours } \\
\text { and their } \\
\text { actions }\end{array}$ & $<0.05$ \\
\hline MH15 & 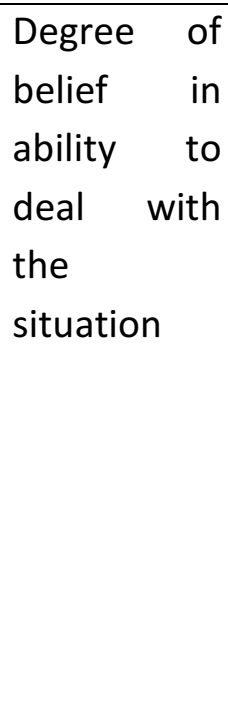 & $\begin{array}{l}\text { Sense of } \\
\text { community } \\
\text { Feeling at } \\
\text { home in } \\
\text { neighbour- } \\
\text { hood } \\
\text { Caring } \\
\text { about } \\
\text { neighbours } \\
\text { and their } \\
\text { actions }\end{array}$ & $\begin{array}{l}<0.05 \\
<0.05 \\
<0.05\end{array}$ \\
\hline
\end{tabular}

In Morpeth, as shown in the Table 8, the regression analysis shows that a sense of community was the predictor for mental health recovery (MHI 5 and SF12) of both men and women. This is consistent with our earlier findings that both men and women had a strong sense of community, and neighbours were an important source of support to them. However, a closer look at the analysis also shows that for men, community dynamics (such as people getting along well) played an important role. Additionally, a correlation analysis of Morpeth data as shown in Table 9 using Spearman's rho shows that the main predictor for mental health recovery of women is their emotional sense of feeling at home in their neighbourhoods, while for men their sense of community, namely social cohesion, expressed through the ability of people of different backgrounds to get along well in their 
neighbourhoods. This measurement of the social cohesion construct (functional construct of closeness to neighbourhood) is aligned with the definition of the concept used by the UK government. The UK Government Commission on Integration and Cohesion report titled Our Shared Future (2007) measures cohesion through the extent to which people of that area from different backgrounds get on well with each other. As such, cohesion is based on; 'people's subjective sense of how relationships work in their local area' (Commission on Integration and Cohesion, 2007, p. 20). In Morpeth, the social cohesion construct, was positively correlated with the men's mental health, while the women's mental health was positively correlated with their emotional sense of feeling at home in the neighbourhood.

Table 8: Predictors for mental health in Morpeth

\begin{tabular}{|l|l|l|l|}
\hline $\begin{array}{l}\text { Dependent } \\
\text { variable }\end{array}$ & \multicolumn{3}{|l|}{$\begin{array}{l}\text { Predictors identified using regression analysis } \\
\text { for Morpeth }\end{array}$} \\
\hline & Males & Females & $\begin{array}{l}\text { P value (level of } \\
\text { significance) }\end{array}$ \\
\hline MHI5 & $\begin{array}{l}\text { Sense of } \\
\text { community }\end{array}$ & $\begin{array}{l}\text { Sense of } \\
\text { community }\end{array}$ & $<0.05$ \\
\hline SF12 & $\begin{array}{l}\text { The people } \\
\text { in this nhbd } \\
\text { get along } \\
\text { well }\end{array}$ & $\begin{array}{l}\text { My } \\
\text { neighbours } \\
\text { and I want } \\
\text { the same } \\
\text { thing from } \\
\text { this nhbd }\end{array}$ & $<0.05$ \\
\hline
\end{tabular}

Table 9

\begin{tabular}{|l|l|l|l|}
\hline $\begin{array}{l}\text { Dependent } \\
\text { variable }\end{array}$ & \multicolumn{3}{|l|}{ Correlation using Spearman's rho in Morpeth } \\
\hline & Males & Females & $\begin{array}{l}\text { P value (level } \\
\text { of significance) }\end{array}$ \\
\hline MHI5 & $\begin{array}{l}\text { Neighbourhood is } \\
\text { a place where } \\
\text { different } \\
\text { backgrounds of } \\
\text { people get on }\end{array}$ & $\begin{array}{l}\text { Feeling home } \\
\text { in the } \\
\text { nhbd }\end{array}$ & \\
\hline
\end{tabular}




\begin{tabular}{|l|l|l|l|}
\hline & $\begin{array}{l}\text { well with each- } \\
\text { other }\end{array}$ & & \\
\hline
\end{tabular}

To summarise, social constructs for mental health (SF12 and MHI5) mobilised as predictors by men include: functional involvement with neighbourhoods and communities; degree of their self-belief in recoveries, while those of women were guided by social constructs of caring, and emotional categories such as feeling at home in neighbourhoods. Thus, we find that the individual strategies of men such as the degree of their self-belief in recovery were aligned with notions of 'control'; while the recovery strategies by women relied on emotional notions such as 'care' and feeling at home. These differences in turn, we argue, arise from the mobilisation of traditional notions of masculinity and femininity by floodaffected men and women.

These findings conform broadly with the research on gendered roles within UK society. Current research within the UK shows that women are disproportionately burdened with caring responsibilities, with men having breadwinning or public roles (Siann et al, 2000; Gershuny 2000; Sullivan and Gurshuny 2001, Sullivan, 2004). Our findings from Tewkesbury and Morpeth about the use of different mental health coping and recovery strategies conform to these traditional notions of femininity associated with caring roles, which require a stronger inter-subjective emotional investment in people and places around them (homes, neighbourhoods). The traditional notion of masculinity as allied with the 'strong bloke' image and the breadwinning public role, is hence associated with a sense of control: such as having a degree of belief in self to deal with the flood situation, possessing control over the surrounding public spaces expressed through social cohesion, and having faith in the community dynamic of getting along well with other persons in the neighbourhood.

This mobilisation of the traditional model of masculinity, namely the strong bloke image is further evidenced in both Tewkesbury and Morpeth in our survey (see Table 10,) which showed that men were found to be seeking less help from people around them as compared to women. Seventy-two percent of women as compared to 55 percent of men from Tewkesbury and 61.6 percent of women and 55.6 percent of men from Morpeth asked for help from family and friends.

Table 10: Help sought after floods from family and friends

\begin{tabular}{|l|l|l|}
\hline $\begin{array}{l}\text { Percentage who have sought } \\
\text { help family and friends }\end{array}$ & Tewkesbury (\%) & Morpeth (\%) \\
\hline Male & 55 & 55.6 \\
\hline Female & 72 & 61.6 \\
\hline
\end{tabular}


This gender difference in the mental health recovery strategies is illustrated through the following excerpt from $\mathrm{T}$, a man aged 65 from Tewkesbury who puts it as follows:

'... as a man I think you have to, you know, stand up and be ... not going to be crying on my wife's shoulders. I think it should be the other way round. Now I know that's a bit old fashioned but that's the way I am. And so I found it very hard but you had to stand up and be counted and get on and deal with it. For her sake because if I went to pieces over it and just lost the plot, who's going to help her? There's nobody is there really? So, I'm not trying to be a martyr here, I'm just trying to say, as a bloke, sometimes you've just got to stop whingeing and get on with it. And that's how I really dealt with it'.

Our finding that traditional notions of masculinity and femininity are mobilised by men and women in mental health recoveries after disasters is further supported by the fact that women in general undertake caring roles after a disaster in the UK and other developed countries. Tapsell et al 2001, 2003 note that in the UK women carried a higher emotional burden of caring for unwell persons after floods (Tapsell and Tunstall, 2001; Tapsell, et al 2003). Women after disasters in the UK often had to take on the added emotional stress of dealing with the anxieties of their children (Fordham and Ketteridge, 1998). Women were found to have higher levels of depression and anxiety following Hurricane Katrina; this difference could be explained by their fears about the wellbeing of the people they cared about (LaJoie et al 2010, Overstreet and Burch, 2008, Willenger, 2008). Elsewhere, such traditional mobilisation of gendered roles after a disaster was also found in the aftermath of the Oakland firestorm in USA (Hoffman, 1999). Similarly Eriksen (2014) finds that traditional gendered norms and roles shape the attitudes and actions of men and women to wildfire response and preparedness in Australia, reinforcing their vulnerabilities in specific ways.

To conclude, our findings from Tewkesbury and Morpeth show that after disasters, gender, place, and mental health are interlinked as shown in our conceptual Figure 1. Distinctly different gendered patterns of strategies for mental health recoveries are discerned, aligned with gendered experience of place: namely, homes and neighbourhoods after disasters. In other words, a web of complex relations is seen between gendered identities, roles, home-neighbourhood places and well-being. This mobilisation of traditional gendered identities can also be seen as a part of the process of recovering the ontological security perceived as being lost after the disasters through displacement, loss of homeneighbourhood place. It is noteworthy that both the predictors of mental health recovery namely - strategies of control (among men) and care (women) are found to be played out in home-neighbourhood places. As noted by Easthope (2004) and Casey (2001), identity formations are not just internal to mind but are practised through bodily interactions (embodied self) in a place, in this case, through gendered interactions in homeneighbourhood places. 


\section{Discussion and Conclusions: Mainstreaming gender and diversity in disasters}

Our findings from UK floods in 2007 and 2008 have shown that gendered experiences of places; homes and communities, can lead to equal but different experiences for disasteraffected men and women. We found that although both men and women, on average, had recovered equally in their mental health after flooding in Tewkesbury and Morpeth, the subjective experience of the flooding as well as the mental health coping and recovery strategies used were different. Gender, place and mental health were found to be interlinked, which is a new contribution to the current literature discussed in the introductory and literature review section.

In particular, we find that readjustment strategies used by men and women when dislocated from their homes and on their return after disasters are very different in terms of mental trauma. We find that trauma as affected through displacement and return to homes and familiar neighbourhoods is redefined. Space and place are at once contracted as well as stretched out. The traumatised gendered body signifies the contracted space and place: the self's relation with self through a reinvigorated traditional gendered self-identity, and the refigured gendered relations within home and neighbourhood its stretching out. This mobilisation of traditional gendered roles and identities enabled the embodied traumatised self to be in a dynamic process of recovering lost ontological security after disaster. This perhaps explains Hoffman's (1999, pp 173) finding of a 'regenesis of traditional gender patterns in the wake of disaster', following the 1991 Oakland firestorm. Such a return was regarded as unusual in the distinctly modern Californian context. More generally, this analysis also points towards the complex relationship between constructions of gendered identities, place, home-neighbourhoods attachments and well being.

These findings suggest that gender as an analytical category is central to developing a more nuanced understanding of relations between home-neighbourhood place, disasters and psychological wellbeing. They also challenge the current gender neutral policy framing by the UK and other EU governments on disaster response and risk reduction strategies, made in the belief that gender gap has been eliminated, as noted in the introduction.

Following from our findings of mostly equal recoveries of mental health; and use of different coping and recovery strategies along the traditional notions of masculinity and femininity, we argue that the idea of gender equality needs to be further deconstructed. After the world conference on women in Beijing in 1995, several governments within the EU adopted gender mainstreaming as a strategy to achieve gender equality. The 1997 Treaty of Amsterdam obliges European Union countries to promote gender equality, legitimizing gender mainstreaming approaches in their legislative policy and practices (Verloo,2007). The Council of Europe gives the definition of gender mainstreaming as '(re)organisation, improvement, development and evaluation of the political processes, so that the gender 
equality perspective is incorporated into all policies, at all levels and in all the stages by the actors normally involved in making political decisions' (Council of Europe, 1998, p. 15). However, as Verloo (2007) maintains, there is a considerable difference in the way in which gender mainstreaming is done in practice. The differences in gender mainstreaming strategies are mainly due to the differences in the way gender equality is conceived by different states.

In the EU, gender equality is mired in three different visions and strategies of gender mainstreaming: gender equality as sameness (using mainstreaming strategy of equal treatment or opportunities); affirming gender differences (using a mainstreaming strategy of special programmes to engage with gender differences); and transformation (gender mainstreaming as a strategy to displace entrenched gendered patterns for new ones) (Verloo, 2007, Walby 2005, Squires 2005, Rees 2005).

A use of gender neutral policy in disasters in UK and some other EU countries is akin to affirming gender equality as sameness, which is treating men and women in same ways after disasters. This, in our view, leads to an undifferentiated understanding of strategies of recoveries which are in reality highly gendered. This dominant gender neutral policy framing, we argue, needs to be replaced by a more critical framing that seeks a more compelling understanding of gender similarities and differences in disasters. More generally within the UK and Europe, building upon Verloo (2005), we argue that it is pertinent to ask 'What is similar, what is different, and what are (shifting) patterns in similarities and differences in the way gender inequality is [to be] understood [...] Which processes of exclusion result from dominant frames [of gender and diversity neutral approach in disasters]? Who and what is excluded' (Verloo, 2005, p.19). Our findings from UK floods indicate that what is currently excluded from framing of disaster policies and practices in UK and some other EU countries is a more nuanced approach to engaging with gender differences. Indeed the recommendations from Pitt review (2008) ${ }^{4}$ undertaken following the UK wide floods in 2007 and their implementation by the Department for Environment, Food and Rural Affair's (DEFRA) are singularly gender neutral (DEFRA, 2012).

The EU requires that member states forbid discrimination on grounds of gender, age, disability, sexuality, race/ethnicity and religion (Krizhan et al 2013). Although our research has focused mainly on gender differences, within the disasters' literature, there is enough evidence to show that gender, along with other diversities, in particular age and disability, and other contextual vulnerabilities can lead to different intersecting gendered experiences (Agustin, 2013; Krizhan et al 2013; Wilson, 2006; Suar et al 2007; Twigg et al, 2011; Help Age International, 2013; Help Age International, 2014; Help Age International/Age and Disability Consortium, 2015, Kelman and Stough, 2015).

\footnotetext{
${ }^{4}$ The UK government had asked Sir Michael Pitt to undertake a comprehensive review of learnings from the widespread floods of 2007 in UK. This report is termed as Pitt review.
} 
We thus advocate the replacement of the dominant gender-neutral policy framing by critical framing which takes into account gender and diversity experiences. This calls for an inclusion of gender and diversity (such as age, disability, LGBT identities and other social categories as relevant) disaggregated data in disasters. Non-inclusion of gender desegregated data often arises from biased perceptions of NGOs and lack of knowledge of humanitarian professionals who continue to look at disasters from gender neutral lens although enough evidence shows gendered mortality and gendered impacts of disasters in practice (Eklund and Tellier, 2012; Mazurana et al 2013). Without a gender and diversity disaggregated data analysis it is difficult to understand the similarities and differences of disaster experience among men and women in nuanced ways, and to develop a contextspecific strategy to address the issues arising from the same. More recently, lobbying by the women's groups at the UN Conference on Disaster Risk Reduction in Sendai, Japan, has led to the Sendai Declaration (2015), which specifically calls for a gender and diversity disaggregated data analysis in disasters. Evidence from our research strongly supports such a call.

The policy evidence discussed above shows that although gender mainstreaming is used in disaster rhetoric, 'gender is still not part of mainstream disaster risk reduction and response practice' (Bradshaw and Fordham, 2013, p.29).Gender is frequently identified only as 'an overarching factor without further analysis or strategy development' in disasters (Hazeleger, 2013, p. 41). To date, studies evaluating the effectiveness of gender mainstreaming in DRR at the operational or programmatic level are very limited. Thus we contend that the multitude of meanings and workings of gender and diversity at local and national levels need to be understood better for a more informed response in policy and practice. More generally, this paper concludes that gender difference in disasters is ubiquitous and thus analyses must include a nuanced gender analysis and ask more probing gendered questions in order to uncover the presence of what are sometimes hidden impacts. 


\section{References}

Adams-Hutcheson, G (2016) Spatialising skin: Pushing the boundaries of trauma geography, Emotion, Space and Society, xxx 1-8

Agustin, L (2013) Gender Equality, Intersectionality and Diversity in Europe, Palgrave Macmillan: New York

Ariyabandu, M (2006) Gender issues in recovery from the December 2004 Indian Ocean tsunami: The case of Sri Lanka, Earthquake Spectra, 22 (S3) S759-S775

Akerkar, S (2007) Disaster Mitigation and furthering women's rights: Learning from the Tsunami, Gender, Technology and Development, 11(3) 357-388

Aksaray, G; Kortan, G; Erkaya, H; Yenilmez, C; \& Kaptanoglu, C (2006) Gender differences in psychological effect of the August 1999 earthquake in Turkey, Nord journal of Psychiatry, 60(5) 387-91

Alam, K \& Rahman Md (2014) Women in natural disasters: A case-study from southern coastal region of Bangladesh, International Journal of Disaster Risk Reduction, 8,68-82

Bankoff, G; Frerks, G; Hilhorst, D (eds) (2004) Mapping vulnerability: disasters, development and people, Earthscan: London

Balgos, B; Gaillard, J C \& Sanz, K (2012) The Warias of Indonesia in disaster risk reduction: The case of the 2010 Mt Merapi eruption, Gender and Development, 20(2) 337-348

Bradshaw, S (2014) Engendering Development and Disasters, Disasters, 39 S1(S54-S71)

Bradshaw, S (2004) Socio-economic Impacts of Natural Disasters: A gender analysis, United Nations Economic Commission for Latin America and the Caribbean (ECLAC) Series Manuales 32, http://www.eclac.org/publicaciones/xml/3/15433/lcl2128i.pdf

Bradshaw, S \& Fordham M (2013) Women, Girls and Disasters, A review for DFID downloaded on $10^{\text {th }}$ August 2015 from

https://www.gov.uk/government/uploads/system/uploads/attachment_data/file/236656/ women-girls-disasters.pdf

Bradshaw, S (2002) Exploring the gender dimensions of reconstruction processes posthurricane Mitch, Journal of International Development, 14, 871-879.

Bradshaw, S (2001) Reconstructing roles and relations: Women's participation in reconstruction in post-Mitch Nicaragua, Gender and Development, 9 (3) 79-87.

Brun, C \& Lund R (2008) Making a home during crisis: Post tsunami recovery in a context of war, Sri Lanka, Singapore Journal of Tropical Geography, 29, 274-287

Blaikie, P; Cannon, T; Davis, I \& Wisner, B (1994) At Risk : Natural Hazards, People's Vulnerability and Disasters, Routledge:London

Bourque, L; Siegel, J; Megumi, K \& Wood, M (2006) Weathering the Storm: The Impact of Hurricanes on Physical and Mental Health, The ANNALS of the American Academy of Political and Social Science, 604 (1) 129-151 
Black, R (2002) Conceptions of home and the political geography of refugee repatriation: Between assumption and contested reality in Bosnia-Herzegovinia, Applied Geography, 22(2) 123-138

Blokland T (2001) Bricks, Mortar, Memories: Neighbourhood and Networks in Collective Acts of Remembering, International Journal of Urban and Regional Network, 25, 268-283

Blunt, A \& Dowling, R (2006) Home, Routledge: London and New York

Brown, B (2012) 'Battered women's shelters in New Orleans Recovery and transformation', in E, David and E, Enarson (eds.), The Women of Katrina: How Gender, Race and Class Matter in an American Disaster, Vanderbilt University Press: Nashville, 179-189.

Carroll, B; Morbey, H; Balogh, R \& Araoz, G (2009) Flood homes, broken bonds, the meaning of home, psychological processes and their impact on psychological health in a disaster, Health and Place, 15, 540-547

Cutter, S (1993) Living with risk, Edward Arnold: London

Cutter, S (1996) Vulnerability to environmental hazards, Progress in Human Geography, 20(4) 529-39

Cupples, J (2007) Gender and Hurricane Mitch: Reconstructing subjectivities after disaster, Disasters, 31(2), 155-175

Council of Europe (1998) Gender mainstreaming: Conceptual framework, methodology and presentation of good practices, Council of Europe, EG-S-MS (98) 2 rev.

Coates, T \& Fordham, M (2000) "You can't replace memories." What disasters reveal about home and identity", paper presented at the 'Geographies of Home' Conference, University College London 8-9 December 2000

Chae, E; Tong, K; Rhee, S \& Henderson, T (2005) The Impact of Flooding on the Mental Health of Affected People in South Korea, Community Mental Health Journal, 41(6) 633645

Commission on Integration and Cohesion (2007) Our shared future, Crown: West Yorkshire

Dell'Osso, L; Carmassi, C; Massimetti, G; Stratta, P; Riccardi, I; Capanna, C, Akishal, KK; Akishal, HS \& Rossi, A (2013) Age, Gender and epicenter proximity effects on post-traumatic stress symptoms in L'Aquila 2009 earthquake survivors, J Affect. Disord, 146(2) 174-180

DEFRA (2012) The Government's Response to Sir Michael Pitt's Review of the summer 2007 Floods: Final Progress Report London: DEFRA 
Dyck, I (2005) Feminist geography, the 'everyday', and local-global relations: hidden spaces of place-making, The Canadian Geographer, 49(3) 233-243

Easthope H (2004) A Place called home, Housing, Theory and Society, 21(3), 128-138

Enarson, E (2012a) Women and girls last? Averting the second post-Katrina disaster, in E. David and E. Enarson (eds.), The Women of Katrina: How Gender, Race and Class Matter in an American Disaster, Vanderbilt University Press: Nashville, 10-14.

Enarson, E (2012b) Women Confronting Natural Disaster: From Vulnerability to Resilience, Lynne Rienner Publishers: Boulder, Colo

Enarson, E \& Chakrabarti D (eds.) (2009) Women, Gender and Disaster: Global Issues and Initiatives, Sage: New Delhi

Enarson, E \& Meyreles, L (2004) International Perspectives on Gender and Disaster: Differences and Possibilities, International Journal of Sociology and Social Policy, 24 (10/11)

Enarson, E \& Fordham, M (2001a) From women's needs to women's rights in disasters, Global Environmental Change Part B, Environmental. Hazards, 3, 133-136,

Enarson, E \& Fordham, M (2001b) Lines that divide, ties that blind : race, class and gender in women's flood recovery in the US and UK, Australian Journal of Emergency Management, 15 (4) $43-52$

Enarson, E \& Morrow, B (1997) A gendered perspective:The voices of women In Hurricane Andrew: Ethnicity, Gender and Sociology of Disasters, (eds) by Peacock, W; Morrow B \& Gladwin, $\mathrm{H}$, Routledge:London and New York, 116-137

Environment Agency (2008) Managing Flood Risk: River Severn Catchment Flood Management Plan, Consultation Draft Plan Bristol, UK: Environment Agency

Ekland, L \& Tellior, S (2012) Gender and international crisis response: do we have the data, and does it matter? Disasters, 36(4) 589-608

Eriksen, C (2014) Gender and wildfire: Landscapes of uncertainty, Routledge: New York.

Fakhruddin, SHM \& Rahman, J (2015) Coping with coaster risk and vulnerabilities in Bangladesh, International Journal of Disaster Risk Reduction, 12, 112-118

Fordham, M \& Ketteridge, A (1998) Men must work and women must weep; Examining gender stereotypes in disasters. In Gendered Terrain of Disasters, (ed) Enarson E \& Morrow, B, Praeger: Westport, Conn, 81-94

Fordham, M (1998) Making Women Visible in Disasters: Problematising the Private Domain Disasters, 22 (2) 126-143 
Fordham, M (2009) 'We can make things better for each other': Women and girls organise to reduce disasters in Central America', in Enarson E \& Chakrabarti D (eds.), Women, Gender and Disaster: Global Issues and Initiatives, Sage: New Delhi 175-188

Foresight Future Identities (2013) Final Project Report. The Government Office for Science, London. page 37,

https://www.gov.uk/government/uploads/system/uploads/attachment data/file/273966/1 3-523-future-identities-changing-identities-report.pdf

Forrest, R \& Kearns, A (2001) Social cohesion, social capital and the neighbourhood, Urban Studies, 38(12) 2125-2143

Fothergill, A (1999) An exploratory study of woman battering in the Grand Forks flood disaster: Implications for community responses and policies, International Journal of Mass Emergencies and Disasters, 17 (1), 79-98

Garrison, C; Weinrich, M; Hardin, S; Weinrich, S; \& Wang, L (1993) Post traumatic stress disorder in adolescents after a hurricane, American Journal of Epidemiology, 138 (7) 522530

Gaillard J.C, Gorman-Murray, A \& Fordham M (2017) Sexual and gender minorities in disaster, Gender, Place \& Culture, 24(1) 18-26.

Gaillard J.C, Sanz K, Balgos, B, Dalisa S, Gorman-Murray A, Smith F \& Toelupe V (2016): Beyond men and women: a critical perspective on gender and disaster, Disasters, online publication

Gershuny, J (2000) Changing Times, Oxford University Press: Oxford

Glesar, G; Green, B; \& Winget C (1981) Prolonged psychological effects of disaster : A study of Buffalo Creek, Academic Press: New York

Gorman-Murray, A (2014) Queer Domicide, Home Cultures, 11 (2) 237-261

Government of United Kingdom (2013): National progress report on the implementation of the Hyogo Framework for Action (2011-2013), United Kingdom, downloaded on 24th August 2015

http://www.preventionweb.net/files/31804 gbr NationalHFAprogress 2011-13.pdf

Gray, S (2008) Editorial: Long-term health effects of flooding, Journal of Public Health, 30 (4), 353-354.

Guillani, V \& Feldman, R (1993) Place attachment in a developmental and cultural context, Journal of Environmental Psychology, 13, 267-274 
Hawkins, R and Maurer, K (2011) 'You fix my community, you have fixed my life': the disruption and rebuilding of ontological security in New Orleans, Disasters, 35(1) 143-159

Hazeleger, T (2013) Gender and disaster recovery: Strategic issues and action in Australia. Australian Journal of Emergency Management, 28 (2) 40-46

Hewitt, K (1983) The idea of calamity in a technocratic age, in Interpretations of Calamity: From the viewpoints of Human Ecology, Allen and Unwin: Boston, London and Sydney, 3-32.

HelpAge International/ Age and Disability Consortium (2015), Minimum Standards for Age and Disability Inclusion in Humanitarian Action, Pilot Version, Help Age International: London

HelpAge International/COSE (2014) Typhoon Haiyan one year on: older people key to recovery, Help Age International: London

HelpAge International (2013) Displacement and older people: the case of the Great East Japan earthquake and tsunami of 2011, HelpAge International: London

Henderson, S \& Elsass, P (2015) Predictors of trauma and distress in Sri Lanka five years after the Indian Ocean tsunami: A cross-sectional study, International Journal of Disaster Risk Reduction, 14, 438-444

Hoffman, S (1999) The regenesis of traditional gender patterns in the wake of disaster in Oliver-Smith A \& Hoffman S (eds) The Angry Earth, Routledge: New York and London, 173191

Hoffman, S (1998) Eve and Adam among the embers: Gender patterns after the Oakland Berkeley Firestorm, in Enarson, E \& Morrow B (eds) The Gendered Terrain of Disasters, Praeger: Westport, Connecticut and London, 55-62.

Houghton, R (2009) Everything became a struggle, absolute struggle: Post-flood increases in domestic violence in New Zealand', in Enarson E \& Chakrabarti D (eds) Women, Gender and Disaster: Global issues and initiatives, Sage: New Delhi, 99-111

Ikeda, K (1995) Gender Differences in Human Loss and Vulnerability in Natural Disasters: A Case Study from Bangladesh, Indian Journal of Gender Studies, 2, 171-93

Ikizer, G; Karanci, N \& Doğulu, C (2015) Exploring Factors Associated with Psychological Resilience Among Earthquake Survivors from Turkey, Journal of Loss and Trauma, Vol 00, No. 00, 1-15, DOI: 10.1080/15325024.2015.1108794

Irshad, H \& Mumtaz, Z (2012) Long-term gendered consequences of permanent disabilities caused by the 2005 Pakistan earthquake, Disasters, 36(3) 452-464 
JBA Consulting (2008) Flooding in Castle Morpeth 6 \& 7 September 2008: Independent Review Draft Report, JBA Consulting, Northampton

Jenkins, P \& Phillips, B (2008) Battered women, catastrophe, and the context of safety after Hurricane Katrina, Feminist Formations, 20 (3) 49-68.

Jonkman, S \& Kelman, I (2005) An analysis of causes and circumstances of flood disaster deaths, Disasters 29(1) 75-97

Kan, M; Sullivan, O; \& Gershuny, J (2011) Gender Convergence in Domestic Work: Discerning the Effects of Interactional and Institutional Barriers from Large-scale Data, Sociology, 45 (2) 234-251

Kelly, M; Dunstan, F; Lloyd, K; \& Fone, D (2008) Evaluating cut points for the MHI-5 and MCS using the GHQ -12: a comparison of five different methods, BMC Psychiatry, 8-10

Kelman, I; Gaillard, J C; Lewis J; \& Mercer, J (2016) Learning from the history of disaster vulnerability and resilience research and practice for climate change, Natural Hazards, (82) 129-143

Kelman, I \& Stough, L (ed) (2015) Disability and Disaster: Explorations and Exchanges, Palgrave Macmillan: New York

Kriznan, A; Skjeje, H; \& Squires J (2013) Institutionalizing Intersectionality: The changing nature of European Equality Regimes, Palgrave Macmillan: UK

LaJoie, A; Sprang, G; \& McKinney W (2010) Long term effects of Hurricane Katrina on the psychological well being of evacuees, Disasters, 34(4) 1031-1,044

Lewis, J (1999) Development in disaster-prone places: studies of vulnerability, Intermediate Technology Publications: London

Mason, V; Andrews, H; \& Upton, D (2010) The psychological impact of exposure to floods Psychology, Health \& Medicine, 15(1) 61-73

Massey, D (1994) Space, Place and Gender, University of Minnesota Press: Minneapolis Massey, D (2005) For Space, Sage publications: London, California and New Delhi Massey, D \& Jess, P (1995) (eds.) A Place in the World?Places Cultures and Globalization, Oxford University Press/ The Open University: Oxford 
Masson, V; Norton A; \& Wilkinson E (2015) Gender and Resilience, Working Paper, ODI:London

Masson, V \& Langston, L (2014) How should the new international disaster risk framework address gender equality? CDKN Policy Brief, ODI: London

Mazurana, D; Benelli P \& Walker, P (2013) How sex- and age-disaggregated data and gender and generational analyses can improve humanitarian response, Disasters, 37(S1) S68-S82

Moore, J (2000) Placing home in context, Journal of Environmental Psychology, 20, 207-217

Morrice, S (2013) Heartache and Hurricane Katrina:recognising the influence of emotion in post-disaster return decisions, Area, 45(1) 33-39

Neumayer, E, \& Plümper, T (2007) The gendered nature of natural disasters: The impact of catastrophic events on the gender gap in life expectancy, 1981-2002, Annals of the Association of American Geographers, 97(3) 551-556

Norris, F; Friedman, M; Watson, P; Byrne C; Diaz E, \& Kaniasty K (2002a) 60,000 disaster victim speak: Part I An empirical review of the empirical literature, 1981-2001, Psychiatry, 65 (3) 207-239

Norris, F; Friedman M, \& Watson P (2002b) 60,000 Disaster Victims Speak: Part II Summary and Implications of the Disaster Mental Health Research, Psychiatry, 65 (3) 240-260

Nomura, S; Parsons, A; Hirabayashi, M; Kinoshita, R; Liao, Yi \& Hodgson, S (2016) Social determinants of mid to long-term disaster impacts on health:A systematic review, International Journal of Disaster Risk Reduction, 16, 53-67

Oliver-Smith, A \& Hoffman, S (1999) The Angry Earth, Routledge: New York and London

O' Keefe, P; Westgate, K \& Wisner, B (1976) Taking the naturalness of natural disasters, Nature, 260

Overstreet, S \& Burch, B (2008) Mental health status of women and children following Hurricane Katrina, in Willenger B (ed) Katrina and the women of New Orleans, New Orleans: New Comb College Centre for Research on Women

Oxfam (2005) The Tsunami's Impact on women: Oxfam Briefing Note, Oxfam International available at http://www.preventionweb.net/files/1502 bn050326tsunamiwomen.pdf

Pavelin, D (2000) Multiple applications of the GHQ-12 in a general population sample: an investigation of long-term retest effects, Social Psychiatry and Psychiatric Epidemiology, 35, 508-512 
Pitt Review (2008) Lessons learnt from the 2007 floods, UK Government

Pincha, C \& Krishna, H (2008) Aravanis: voiceless victims of the tsunami, Humanitarian Exchange, 41, 41-43

Reyes, D \& Lu, J (2016) Gender dimension in disaster situations: A case study of flood prone women in Malabon City, Metro Manila, International Journal of Disaster Risk Reduction, 15, 162-168

Rees, T (2005) Reflections on the Uneven Development of Gender Mainstreaming in Europe, International Feminist Journal of Politics, 4, 555-74.

Sawa, M; Osaki, Y \& Koishikawa H (2013) Delayed recovery of caregivers from social disfunction and psychological distress after the Great East Japan Earthquake, J. Affect. Disord, 148 (2-3) 413-417

Stuart-Menteth, (2007) UK Summer 2007 Floods Risk, Management Solutions Ltd: London

Sullivan, O (2004) Changing Gender Practices within the Household: A Theoretical Perspective, Gender \& Society,18 (2) 207-223

Sullivan, O \& J Gershuny. (2001) Cross-national changes in time-use: Some sociological (hi)stories re-examined. British Journal of Sociology, 52 (2) 331-347

Siann, G; Riley, R; Wilson, F; \& Callaghan, M (2000) Gender and home and work in Britain: Continuities and Change, Journal of Applied Social Psychology, 30(12) 2491-2512

Squires, J (2005) Evaluating Gender Mainstreaming in the Context of EU Diversity Strategies, ECPR Joint Sessions of Granada, 14-19 April 2005, Workshop on 'The Future of Gender Equality in the European Union', downloaded on $15^{\text {th }}$ July 2015 http://ecpr.eu/Filestore/PaperProposal/7caef9fe-e3dd-42c7-bd5c-945351814e36.pdf

Suar, D; Mishra, S; \& Khuntia, R (2007) Placing age differences in the context of the Orissa supercylone: Who experiences psychological distress? Asian Journal of Social Psychology, $10,117-122$

Suzuki, Y; Yabe, H; Yasumura S; Ohira, T; Niwa, S; Ohtsuru, A; Mashiko, H; Maedab, M \& Abe, $M(2015)$ Psychological distress and the perception of radiation risks: the Fukushima health management survey; Bull World Health Organ, 93,598-605

Tapsell, S \& Tunstall, S (2001): The health and social effects of the june 2000 flooding in the North East Region, Report to Environmental Agency, Thames Region, Flood Hazard Research Centre, Middlesex University: Enfield 
Tapsell, S; Tunstall, S; \& Wilson T (2003) Banbury and Kidlington four years after the flood:an examination of the long term effects of flooding, Environment Agency: Bristol

Tapsell, S \& Tunstall S (2008) I wish I'd never heard of Banbury: The relationship between 'place' and the health impacts from flooding, Health and Place, (14) 133-154

Tedeschi, R \& Calhoun, L (2004) Posttraumatic growth: Conceptual foundations and empirical evidence, Psychological Inquiry, 15(1) 1-18

Toyabe, S; Shioiri, T; Kuwabara, H; Endoh, T; Tanabe, N; Someya, T \& Akazawa, K (2006) Impaired psychological recovery in the elderly after the Nigata-Chuetsu Earthquake in Japan: a population based study, BMC Public Health, 6, 230

Twigg, J; Kett, M; Bottemley, H; Tan, L; \& Naseriddin H (2011) Disability and Public Shelter in Emergencies, Environmental Hazards, 10 (3-4) 248-61

United Nations (2009) Making Disaster Risk Reduction Gender-Sensitive Policy and Practical Guidelines, UNISDR, UNDP, IUCN: Geneva, Switzerland

UNISDR (2013) Implementing the Hyogo Framework for Action in Europe Regional Synthesis Report 2011-2013, UNISDR, European Commission and Europa: Brussels and Strasbourg Cedec. Downloaded from http://www.preventionweb.net/files/33275 hfa13web.pdf on 24th August 2015

Varela, E; Koustouki, V; Davos, C \& Kiriakidou, E (2008) Psychological consequences among adults following the 1999 earthquake in Athens, Greece, Disasters, 32 (2) 280-91

Van Loey, N; Van de Scoot, R; Faber A (2012) Post traumatic stress symptoms after exposure to two fire disasters: comparative study, PLoS One, 7(7) e41532

Verloo, M (2005) Mainstreaming Gender Equality in Europe. A Frame Analysis Approach, The Greek Review of Social Research, Special Issue: Differences in the Framing of Gender Inequality as a Policy Problem across Europe, 117 (B) 11-34.

Verloo, M (ed) (2007) Multiple meanings of gender equality: A Critical Frame Analysis of Gender Policies in Europe, CEU Press: Budapest

Walby, S (2005) Gender mainstreaming: Productive tensions in theory and practice, Social Politics,12(3) 321-343

Ware, J; Gandek, B; \& Kosinski, M (1998) The equivalence of SF36 summary health scores estimated using standard and country specific algorithms in 10 countries: results from IQOLA project, International quality of life assessment; Journal of Clinical Epidemiology, 51(11) 1167-1170 
Ware, J (2002) Identifying populations at risk: functional impairment and emotional distress, Manage Care, Vol 11(10) 15-17

Wisner, B., Blaikie, P., Cannon, T \& Davis, I (2004) At Risk : Natural Hazard, People's vulnerability and Disasters, Routledge: London and New York

Wilson, N (2006) Hurricane Katrina: unequal opportunity disaster, Public Policy and Aging Report, 16(2)8-13

Willinger, B (2008) Katrina and the women of New Orleans, New Orleans: New Comb College Centre for Research on Women

Yoshii H, Saito H, Kikuchi S, Ueno T, Sato K (2014) Report on maternal anxiety 16 months after the great East Japan earthquake disaster: anxiety over radioactivity, Glob J Health Sci, 6(6) 1-10 